\title{
Antimicrobial, Analgesic and Anti - Inflammatory Activity Reported on Tamarindus indica Linn Root Extract
}

\author{
Sangeeta Gupta ${ }^{1}$, Amit Singh ${ }^{2}$
}

Sangeeta Gupta ${ }^{1}$, Amit Singh $^{2}$ 'Department of Pharmacognosy, Technocrates College of Pharmacy, Piplani, Anand nagar, Bhopal, Madhya Pradesh, INDIA.

2Department of Pharmacology, The Pharmaceutical College, Samaleshwari vihar, Barpali, Barghar, Orissa, INDIA.

\section{Correspondence}

Sangeeta Gupta,

Department of Pharmacognosy, Technocrates College of Pharmacy, Piplani, Anand nagar, Bhopal, Madhya Pradesh, INDIA.

Phone no: $91+9627953280$

E-mail: nicesangi@gmail.com

\section{History}

- Submission Date: 06-12-16;

- Review completed: 18-12-16;

- Accepted Date: 02-02-17.

DOI : 10.5530/pj.2017.3.70

Article Available online http://www.phcogj.com/v9/i3

\section{Copyright}

(c) 2017 Phcog.Net. This is an openaccess article distributed under the terms of the Creative Commons Attribution 4.0 International license.

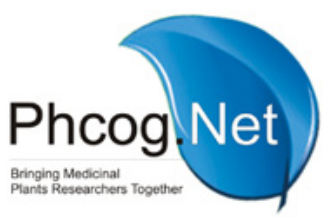

\begin{abstract}
Objective: Tamarindus indica (Family- Fabaceae) show various folkloric uses in treatment of various ailments such as rheumatisum, dysentery, jaundice etc. Aim: The research was conducted to investigate its phytoconstituients and various activity such as antimicrobial, analgesic \& anti-inflammatary of AETIRE. Method: The antimicrobial activity was performed on 4 bacterial stains containing (B.subtilis, S.aureus, P. aeruginosa \& E.coll) on AETIRE using Disc diffusion method. The Analgesic activity was tested by thermal and chemical induced pain through Hot plate and AAIWT. And carrageenan induced rat paw oedema model is used to evaluate antiinflammatory activity. Result: Phytoconstituients such as tannins, alkaloids, saponins, flavonoids and carbohydrates present in both the extract. The maximum zone of inhibition of about $21 \mathrm{~mm} \& 22 \mathrm{~mm}$ was shown on B.subtilis strain by both the extract when compared with standard drug (Tetracycline \& Gentamycin). In AAIWT and hot plate test the AETIRE of concentration $(100,200 \mathrm{mg} / \mathrm{kg}$ ) produce significant dose-dependent inhibition of pain response with maximum $54.33 \%$ protection against acetic acid induced pain and about $74.83 \%$ inhibition against thermally induced pain by the aqueous extract $200 \mathrm{mg}$. \& the anti- inflammatory activity shown by AETIRE (100 \& 200mg/kg) caused significant dose dependent inhibition of oedema with maximum $45.94 \%$ inhibition in the Carrageenan induced rat paw oedema by the AE. Conclusion: Therefore the AE of Tamarindus indica root was more effective in showing analgesic and anti-inflammatory activity when compared to the standard drug in each model while ethanol extract show effective antimicrobial activity.
\end{abstract}

Key words: Antimicrobial, Fabaceae, Analgesic, Anti- inflammatory activity, Tamarindus indica.

\section{INTRODUCTION}

The plant Tamarindus indica locally known as imli all over India belongs to family Fabaceae. The plant is extensively grown in all over the Bangladesh, is widely used all over Tropical Africa, Sudan, India, Pakistan for different purposes. Different parts of this plant are used in the indigenous system of medicine (Ayurveda, Unani, Siddha, Homeopathic) for the treatment of variety of human ailments. ${ }^{1,2}$ According to ethnobotanical survey the various parts of Tamarindus indica is used in treatment of many diseases such as fever, malaria, stomach ache, wound, ${ }^{3}$ diabetes, ${ }^{4}$ rheumatism, ulcer, sore throat, eye infection and in jaundice ${ }^{5}$ Further the pharmacological investigation on Tamarindus indica the leaf extracts show antimicrobial, ${ }^{6}$ antidiabetic, ${ }^{7}$ Hypolipidemic, ${ }^{8}$ antiasthmatic ${ }^{9}$ and wound healing property. ${ }^{10}$ While the fruit pulp and seed shows antioxidant, ${ }^{11}$ antimicrobial, ${ }^{12}$ hepatoprotective, ${ }^{13}$ immunomodulatory ${ }^{14}$ and laxative property..$^{15}$ and the bark and roots are used as analgesic, ${ }^{16}$ anthelmintic ${ }^{17}$ and in menorrhagia in woman. ${ }^{18}$

The clinical efficiency of many existing antibiotics is being threatened by the emergence of multi- drug resistant pathogens. Many infectious diseases have been known to be treated with herbal remedies throughout the history of mankind. ${ }^{19}$ The increasing failure of the chemotherapeutics and antibiotic resistance exhibited by pathogenic microbial infectious agents have led to the screening of several medicinal plants for their potential antimicrobial activity. ${ }^{20}$

Pain is an unpleasant sensory and emotional experience which we primarily associate with tissue damage or describe in terms of such damage or both ${ }^{21}$ While Inflammation is a pathophysiological response of living tissue to injuries that lead to local accumulation of fluids and blood cells the complex events and mediators involved in inflammatory reaction can induce or aggravate many diseases. ${ }^{22}$ However studies have been continuing on analgesic and anti-inflammatory diseases and the side effects of the non -steroidal anti-inflammatory drugs (NASAIDs) and opioids drugs pose major problem during their clinical use. Hence the search for the new drugs with more powerful analgesic and anti-inflammatory activity and having minimal side effects is necessary. ${ }^{23}$ However it has been seen from various literature reviews that no scientific report has been seen on the root of Tamarindus indica. Hence, the aim of the present study on the basis of various evidence is to investigate the antimicrobial, analgesic and anti- inflammatory activity on the root of Tamarindus indica. 


\section{MATERIALS AND METHODS}

\section{Plant Materials}

The fresh root of Tamarindus indica plant was collected from Bhopal district (M.P), India during the month of November 2011. The specimen herbarium (564/boi/safia/12) was identified by the Taxonomist, Department of Botany, Safia College of Science, Bhopal (MP), India.

\section{Chemicals}

Various chemicals such as Aspirin, Pentazocin, Acetic acid, Carrageenan, Agar, Tetracycline and gentamycin were procured from S. K Scientific chemicals, Moradabad, India. And food pellets for feeding experimental rats were supplied by Pranav Agro Industries, Vadodara, Gujrat.

\section{Preparation of Extract}

The root of the plant is shade dried and powdered. The extraction of powdered root was performed by hot extraction method by soxhlet apparatus. The powdered root was then extracted with solvents of increasing polarity, such as petroleum ether, ethanol and water. The individual extract was then filtered respectively through Whatman filter paper to remove impurities and volume is reduced by vacuum evaporator and further evaporated on water bath till dryness and collected. All extracts were stored in well closed container at room temperature.

\section{Test micro-organism}

The test organisms were clinical isolates from the stock culture of Institute of Microbial Technology (MTCC), Chandigarh, India. They include Staphylococcus aureus (MTCC 3160), Escherichia coli (MTCC 1698), Bacillus subtilis (MTCC 2757), and Pseudomonas aeruginosa (MTCC 6458). Each of these microorganisms was subculture unto nutrient broth to test for viability and subsequently on nutrient agar slants and kept at $4^{\circ} \mathrm{C}$ prior to susceptibility testing.

\section{Animals}

Male and Female Albino wistar rats (100-200g) were used in the studies of analgesic and anti- inflammatory activity. The animals were maintained in clean polypropylene cages with $12 \mathrm{~h}$ light and dark cycle at a temperature of $26-28^{\circ} \mathrm{C}$ and supplied with pellet diet and water ad libitum. The animals were acclimatized to laboratory condition for one week before starting the experiment. The experimental protocol approved by Institutional animal ethical committee allotted registration. No. (TIT/ IAEC/831/p'cog/2012/16).

\section{Phytochemical screening}

The phytochemical examination of ethanol and aqueous extracts of Tamarindus indica root was performed by various standard procedure for the detection of secondary metabolite such as alkaloids, flavonoids, saponins, glycosides, tannins etc. ${ }^{24,25}$

\section{Toxicity study}

Male Albino wistar rat were used for acute toxicity study according to OECD guidelines. Distilled water was used as vehicle to suspend the extracts and administered orally. The plant extract was forced through gavage to the rats at doses of - 50, 100,200, 300, 500 and 1000 and 2000 $\mathrm{mg} / \mathrm{kg}$. Immediately after dosing, the animals were observed for $2 \mathrm{~h}$ continuously after treatment for behavioural changes such as convulsion, hyperactivity, sedation, ataxia and increased diuresis and for mortality at the end of $24 \mathrm{~h}, 48 \mathrm{~h}$ and $72 \mathrm{~h}$ respectively. Further if the animals are survived they were kept and further observed for the sign of death or toxicity for the next 7 days. ${ }^{26}$

\section{Determination of Antimicrobial Activity}

In-vitro antimicrobial screening was generally performed by paper disc diffusion method for the primary selection of the compound as therapeutic agent. ${ }^{27}$ The antimicrobial activity was performed on the extract of the root of Tamarindus indica against four pathogenic bacteria like Bacillus subtilis, Staphylococcus aureus, Escherichia coli and Pseudomonas aeruginosa (Two Gram positive and two Gram negative). The direct colony suspension method was used for inoculums preparation..$^{28}$ Tetracycline and Gentamycin were used as the standard drug for comparative purposes with the extract. Stock solution of the standard drug were prepared in sterile distilled water to give a concentration of $100 \mathrm{mg} / \mathrm{ml}$ and the test extracts were also prepared at the same concentration. Sterile discs ( $0.5 \mathrm{~mm}$ diameter) made of Whatman filter paper were dipped into the test extract and were put onto the agar surface after complete drying. Plates were then incubated at $35^{\circ} \mathrm{C}$ for $24 \mathrm{~h}$. After incubation plates were observed for zones of inhibition, and their diameter were measured including the diameter of the disc. ${ }^{29}$

\section{Determination of Analgesic activity}

\section{Hot plate method}

The animals of either sex were weighed and divided into six groups of six animals in each. Group I (distilled water, $10 \mathrm{ml} / \mathrm{kg} \mathrm{p.o}$ ) served as control group. Group II (pentazocine $30 \mathrm{mg} / \mathrm{kg}$ p.o) served as standard and Group III and IV were treated with aqueous and ethanol extracts at a dose of 100 and $200 \mathrm{mg} / \mathrm{kg}$ body weight. The reaction time of animal was noted down on hot plate at 30, 45, 60 and 90 minutes after the above treatment. The basal reaction was the time taken by observing hind paw licking and jump response in animals while placed on hot plate which was maintained at constant temperature $55^{\circ} \mathrm{C}$. A cut off period of $15 \mathrm{sec}$ was taken for complete analgesia and to avoid further tissue damage. ${ }^{30}$ The percent inhibition of activity at each interval can be calculated by the formula :-

\section{Percent Inhibition $=\left(\mathrm{P}_{\mathrm{T}}-\mathrm{P}_{0}\right) /\left(\mathrm{X}-\mathrm{P}_{\mathrm{T}}\right) \times 100$}

Where $\mathrm{P}_{T}$ is post treatment latency, $\mathrm{P}_{0}$ is the pre-treatment latency and $\mathrm{X}$ is the cut-off time of $15 \mathrm{sec}$

\section{Acetic acid induced writhing test}

Animals were divided into six groups of six animals each and the drug treatments were given as per the hot plate method for control, standard Aspirin (100mg/kg p.o) and test. Thirty minutes prior to the administration of Acetic acid ( $0.6 \%$ or $1 \mathrm{ml} / \mathrm{kg}$ body weight i.p). The writhing effect is seen which is indicated by stretching of abdomen with simultaneous stretching of at least one hind limb. This was observed for 15 minutes and change in number of writhing in test group was compared with standard. And the percentage inhibition was calculated by the formula:-

\section{Percent inhibition $=(1-\mathrm{Nt} / \mathrm{Nc}) \times 100$}

Where, Nt is the average number of writhing in treated group and Nc is the average number of writhing in control group ${ }^{30,31}$

\section{Determination of Anti - inflammatory activity}

Male Albino rats were used for anti- inflammatory study. They were divided into five groups. ( $\mathrm{n}=5$ animals in each group). Group I served as control (distilled water, $10 \mathrm{ml} / \mathrm{kg}$ p.o) Group II served as standard group (Aspirin, 200mg/kg p.o) and Group III and IV received 100 and 200 $\mathrm{mg} / \mathrm{kg}$ of both the test extract. One hour after the administration of the 
various agents, oedema was induced by injection of carrageenan $(0.1 \mathrm{ml}$, $1 \%, \mathrm{w} / \mathrm{v}$ in saline) into the sub plantar tissue of the right hind paw of all the animals. The relative increase in paw volume was measured using plethysmometer at an interval of 1, 2, 3, 4 and $5 \mathrm{~h}$ after carrageenan injection. ${ }^{32}$ The increase in paw volume of Group II, III and IV were compared with the Group I. The percentage inhibition of oedema volume was calculated by using formula.

$$
\text { Percent inhibition }=(1-\mathrm{Vt} / \mathrm{Vc}) \times 100
$$

Where, Vt is increase in paw volume in treated group and Vc is increase in paw volume in control group. ${ }^{33}$

\section{Statistical Analysis}

All observation is expressed as mean \pm SEM and calculation of the statistical significance (P value) was done by using ANOVA followed by Dunnett's test. A value of $\mathrm{P}<0.01, \mathrm{P}<0.05$ indicated as significant difference when compared with the control.

\section{RESULT}

The Phytochemical screening of ethanol and aqueous extract of Tamarindus indica root revealed the presence of various active constituents in both the extract (Table 1). It confirms the presence of tannins, alkaloids, saponins, flavonoids, phenol, steroids and carbohydrate.

In the acute toxicity study, no behavioural changes was observed during the first 24 hour period at the tested doses of 50, 100, 200, 300, 500 and 1000 and $2000 \mathrm{mg} / \mathrm{kg}$ and the animal showed no mortality rate due to toxicity within $72 \mathrm{~h}$ and further within 7 days of observation.

The antimicrobial result as given in (Table 2) reveal that, the activity of crude extract of the root of Tamarindus indica plant is encouraging. The antimicrobial activity is shown by each microorganisms used in the study (Bacillus subtilis, Staphylococcus aureus, Escherichia coli and Pseudomonas aeruginosa) The maximum zone of inhibition is shown on $\mathrm{Ba}$ cillus subtilis strain by ethanol extract with $22 \mathrm{~mm}$ diameter while with aqueous extract it is about $21 \mathrm{~mm}$ diameter so the ethanol extract of Tamarindus indica root is more significant when compared with standard drug Tetracycline and Gentamycin.

The analgesic activity was performed by Hot plate method and Acetic acid induced writhing test which show dose dependent inhibition in both aqueous and ethanol extract as mentioned in (Table 3 and 4). The percent pain inhibition seen by the extract resulted to be $25.80 \%, 74.83 \%$ in aqueous extract of concentration (100mg and $200 \mathrm{mg}$ ) and about $29.98 \%, 66.60 \%$ in ethanol extract (100mg and $200 \mathrm{mg}$ ) within $90 \mathrm{~min}$ of pain latency by hot plate test. While in acetic acid induced writhing test the percent protection from pain caused by acetic acid was found to be $39.82 \%, 54.33 \%, 23.75 \%$ and $33.71 \%$ in aqueous and ethanol extract at a concentration of $100 \mathrm{mg}$ and $200 \mathrm{mg}$. Therefore analgesic activity is seen to be quite significant in aqueous extract $(200 \mathrm{mg})$ when compared with the standard drug in both the model

While the anti - inflammatory activity performed by carrageenan induced rat paw oedema (Table 5) revealed percent inhibition against carrageenan caused oedema to be $29.72 \%, 45.74 \%$ by the aqueous extract at both the concentration $100 \mathrm{mg} \& 200 \mathrm{mg}$ and $32.43 \%, 37.83 \%$ in ethanol extract at time interval of $5 \mathrm{~h}$. So the aqueous extract at $200 \mathrm{mg}$ show significant anti-inflammatory activity when compared with the standard drug (Aspirin).

\section{DISCUSSION}

Exploring the healing power of plants is an ancient concept and for centuries people have been trying to develop various drugs from plants which has effective activity and less side effects. ${ }^{34}$ In literature it has been indicated that medicinal plants are the backbone of traditional medicine and the activity of plant extract is due to different chemical agent in the extract which were classified as active compounds. ${ }^{35}$ In plants various phytochemical constituents such as tannins, flavonoids, alkaloids and several other aromatic compounds are secondary metabolites of plants that serve as defence mechanisms against predation by many microorganisms, insects and herbivores and act as a phytoprotectants and respond to envoirmental stress condition. ${ }^{36,37}$ This may therefore explain the demonstration of antimicrobial activity by the root extracts of Tamarindus indica. It has been also reported that Tamarindus indica leaf extract show antimicrobial property due to the presence of secondary metabolites such as phenols and flavonoids. ${ }^{6}$ The demonstration of antibacterial activity against both gram positive and gram negative bacteria may be indicative of the presence of broad spectrum antibiotic compounds. ${ }^{38}$

In the recent study ethanol \& aqueous extract of Tamarindus indica root has been taken in which the ethanol extract show effective antimicrobial property (Table 2) against various microorganisms such as B.subtilis,

\section{Table 1: Phytochemical screening of Tamarindus indica extract}

\begin{tabular}{cccc}
\hline S.no & Active constituents & $\begin{array}{c}\text { Ethanol } \\
\text { extract }\end{array}$ & $\begin{array}{c}\text { Aqueous } \\
\text { extract }\end{array}$ \\
\hline 1 & Alkaloids & + & -- \\
2 & Amino acids & - & - \\
3 & Steroids and Triterpenoids & - & + \\
4 & Tannins & ++ & ++ \\
5 & Saponins & + & + \\
6 & Carbohydrates & + & + \\
7 & Flavonoids \& polyphenols & ++ & +++ \\
8 & Cardiac glycosides & - & - \\
9 & Anthraquinone glycosides & - & - \\
\hline
\end{tabular}

Symbol (+) and (-) shows presence and absence of the active constituents in the extract

Table 2: Antimicrobial activity of Tamarindus indica root extract

\begin{tabular}{ccccc}
\hline Test sample & \multicolumn{4}{c}{ Zone of Inhibition $(\mathrm{mm})$} \\
\cline { 2 - 5 } & S. aureus & B. subtilis & P. aeruginosa & E. coli \\
\hline Aqueous extract & 18 & 21 & 15 & 11 \\
Ethanol extract & 20 & 22 & 17 & - \\
Tetracycline & 25 & 28 & 26 & 27 \\
Gentamycin & 26 & 27 & 28 & 29 \\
\hline
\end{tabular}

Table 3: Analgesic effect shown by root of Tamarindus indica root extract by Acetic acid induced writhing method

\begin{tabular}{cccc}
\hline Treatment & Dose (p.o) & Number of writhing in 15 min & \% Protection \\
\hline Control & $10 \mathrm{ml} / \mathrm{kg}$ & $70.3 \pm 2.27$ & - \\
Aspirin & $100 \mathrm{mg} / \mathrm{kg}$ & $22.1 \pm 1.32^{* *}$ & 68.50 \\
& $100 \mathrm{mg} / \mathrm{kg}$ & $42.30 \pm 2.89^{*}$ & 39.82 \\
Test I & $200 \mathrm{mg} / \mathrm{kg}$ & $32.10 \pm 2.48^{* *}$ & 54.33 \\
& $100 \mathrm{mg} / \mathrm{kg}$ & $53.60 \pm 2.60^{*}$ & 23.75 \\
Test II & $200 \mathrm{mg} / \mathrm{kg}$ & $46.60 \pm 3.41^{*}$ & 33.71 \\
\hline
\end{tabular}


Table 4: Analgesic effect of the Tamarindus indica root extract by Hot plate method

\begin{tabular}{|c|c|c|c|c|c|c|}
\hline \multirow{2}{*}{ Group } & \multirow{2}{*}{ Dose } & \multirow{2}{*}{$\begin{array}{l}\text { Pain latency before } \\
\text { administration of drug } \\
\text { (in sec) }\end{array}$} & \multicolumn{4}{|c|}{ Pain latency after administration of drug (in sec) \& percent inhibition } \\
\hline & & & $30 \mathrm{~min}$ & $45 \mathrm{~min}$ & $60 \mathrm{~min}$ & $90 \mathrm{~min}$ \\
\hline Control & $10 \mathrm{ml} / \mathrm{kg}$ & $2.00 \pm 0.30$ & $\begin{array}{c}2.16 \pm 0.30 \\
(1.23)\end{array}$ & $\begin{array}{c}2.33 \pm 0.30 \\
(2.53)\end{array}$ & $\begin{array}{c}2.50 \pm 0.42 \\
(3.84)\end{array}$ & $\begin{array}{c}2.83 \pm 0.22 \\
(6.38)\end{array}$ \\
\hline Pentazocine & $30 \mathrm{mg} / \mathrm{kg}$ & $3.50 \pm 0.50$ & $\begin{array}{c}6.16 \pm 0.47^{* *} \\
(23.13)\end{array}$ & $\begin{array}{c}8.00 \pm 0.93^{* *} \\
(39.13)\end{array}$ & $\begin{array}{c}11.16 \pm 0.74 * * \\
(66.60)\end{array}$ & $\begin{array}{c}13.83 \pm 1.13^{* *} \\
(89.82)\end{array}$ \\
\hline \multirow{2}{*}{$\begin{array}{l}\text { Aqueous } \\
\text { extract }\end{array}$} & $100 \mathrm{mg} / \mathrm{kg}$ & $2.33 \pm 0.55$ & $\begin{array}{c}3.50 \pm 0.76 \\
\quad(9.23)\end{array}$ & $\begin{array}{c}4.30 \pm 0.66 \\
(15.54)\end{array}$ & $\begin{array}{c}5.00 \pm 0.44 \\
(21.07)\end{array}$ & $\begin{array}{c}5.60 \pm 0.91 \\
(25.80)\end{array}$ \\
\hline & $200 \mathrm{mg} / \mathrm{kg}$ & $3.16 \pm 0.30$ & $\begin{array}{c}6.00 \pm 0.51^{*} \\
(23.98)\end{array}$ & $\begin{array}{c}7.50 \pm 0.76^{* *} \\
(36.65)\end{array}$ & $\begin{array}{c}10.00 \pm 0.68^{* *} \\
(57.77)\end{array}$ & $\begin{array}{c}12.02 \pm 0.57^{\star *} \\
(74.83)\end{array}$ \\
\hline \multirow{2}{*}{$\begin{array}{l}\text { Ethanol } \\
\text { extract }\end{array}$} & $100 \mathrm{mg} / \mathrm{kg}$ & $2.16 \pm 0.30$ & $\begin{array}{c}3.83 \pm 0.65 \\
(13.00)\end{array}$ & $\begin{array}{c}4.00 \pm 0.57 \\
(14.33)\end{array}$ & $\begin{array}{c}5.66 \pm 0.55 \\
(27.25)\end{array}$ & $\begin{array}{c}6.01 \pm 0.12 \\
(29.98)\end{array}$ \\
\hline & $200 \mathrm{mg} / \mathrm{kg}$ & $3.00 \pm 0.44$ & $\begin{array}{c}6.16 \pm 0.47^{*} \\
(26.33)\end{array}$ & $\begin{array}{c}6.33 \pm 0.49^{*} \\
(27.75)\end{array}$ & $\begin{array}{c}9.33 \pm 0.61 \text { * } \\
(52.75)\end{array}$ & $\begin{array}{c}11.00 \pm 0.63^{*} \\
(66.60)\end{array}$ \\
\hline
\end{tabular}

Table 5: Anti - inflammatory effect of Tamarindus indica root extract on the carrageenan induced rat paw oedema in rats.

\begin{tabular}{|c|c|c|c|c|c|c|}
\hline \multirow[b]{2}{*}{ Group } & \multirow[b]{2}{*}{ Dose } & \multicolumn{5}{|c|}{ Change in paw volume after drug administration $(\mathrm{ml})$ and \% Inhibition } \\
\hline & & $1 \mathrm{~h}$ & $2 \mathrm{~h}$ & $3 \mathrm{~h}$ & $4 \mathrm{~h}$ & $5 \mathrm{~h}$ \\
\hline Control & $10 \mathrm{ml} / \mathrm{kg}$ & $0.64 \pm 0.06$ & $0.76 \pm 0.06$ & $0.80 \pm 0.87$ & $0.78 \pm 0.08$ & $0.74 \pm 0.08$ \\
\hline Aspirin & $200 \mathrm{mg} / \mathrm{kg}$ & $\begin{array}{c}0.32 \pm 0.03^{\star *} \\
\quad(50.00)\end{array}$ & $\begin{array}{c}0.36 \pm 0.06^{* *} \\
(52.63)\end{array}$ & $\begin{array}{c}0.42 \pm 0.05^{\star *} \\
\quad(47.50)\end{array}$ & $\begin{array}{c}0.36 \pm .03^{* *} \\
(53.84)\end{array}$ & $\begin{array}{c}0.30 \pm 0.07^{* *} \\
(59.45)\end{array}$ \\
\hline \multirow[t]{2}{*}{ Aqueous extract } & $100 \mathrm{mg} / \mathrm{kg}$ & $\begin{array}{c}0.50 \pm 0.07 \\
(21.80)\end{array}$ & $\begin{array}{c}0.54 \pm 0.07^{\star} \\
(28.94)\end{array}$ & $\begin{array}{c}0.58 \pm 0.05^{*} \\
(27.50)\end{array}$ & $\begin{array}{c}0.56 \pm 0.04^{*} \\
(28.20)\end{array}$ & $\begin{array}{c}0.52 \pm 0.05^{*} \\
\quad(29.72)\end{array}$ \\
\hline & $200 \mathrm{mg} / \mathrm{kg}$ & $\begin{array}{c}0.42 \pm 0.03^{*} \\
(34.37)\end{array}$ & $\begin{array}{c}0.44 \pm 0.05^{\star *} \\
\quad(42.10)\end{array}$ & $\begin{array}{c}0.48 \pm 0.05^{\star *} \\
(40.00)\end{array}$ & $\begin{array}{c}0.46 \pm 0.09^{\star *} \\
\quad(41.02)\end{array}$ & $\begin{array}{c}0.40 \pm 0.08^{* *} \\
(45.94)\end{array}$ \\
\hline \multirow[t]{2}{*}{ Ethanol extract } & $100 \mathrm{mg} / \mathrm{kg}$ & $\begin{array}{c}0.52 \pm 0.03 \\
\quad(18.75)\end{array}$ & $\begin{array}{c}0.56 \pm 0.06^{*} \\
(26.31)\end{array}$ & $\begin{array}{c}0.60 \pm 0.08^{*} \\
(25.00)\end{array}$ & $\begin{array}{c}0.54 \pm 0.07^{*} \\
(30.67)\end{array}$ & $\begin{array}{c}0.50 \pm 0.07^{\star} \\
(32.43)\end{array}$ \\
\hline & $200 \mathrm{mg} / \mathrm{kg}$ & $\begin{array}{c}0.48 \pm 0.05^{*} \\
(25.01)\end{array}$ & $\begin{array}{c}0.52 \pm 0.05^{*} \\
\quad(31.57)\end{array}$ & $\begin{array}{c}0.56 \pm 0.04^{* *} \\
(30.00)\end{array}$ & $\begin{array}{c}0.52 \pm 0.03^{*} \\
(33.35)\end{array}$ & $\begin{array}{c}0.46 \pm 0.08^{* *} \\
(37.83)\end{array}$ \\
\hline
\end{tabular}

Values are in mean \pm SEM, $n=5$ for all groups (One way ANOVA followed by Dunnett's multiple compression test). ${ }^{*} \mathrm{P}<0.01,{ }^{*} \mathrm{P}<0.05$ when compared with the control group.

P.aeruginosa, St.aureus and E.coli as compared to aqueous extracts. Different solvents have been reported to have the capacity to extract different phytoconstituents depending on their solubility or polarity in the solvent. ${ }^{37}$ Ethanol extracts in this study might have had higher solubility for more phytoconstituents, consequently the highest antibacterial activity

Peoples are getting inclined towards natural sources of drugs because the various analgesic and anti-inflammatory drugs such as non - steroidal anti-inflammatory drugs and opioids present in the market induce various side effects like gastric ulcer and hepatotoxicity. ${ }^{39}$ In the present study, the analgesic and anti-inflammatory effects of aqueous and ethanol extract of Tamarindus indica root were evaluated to verify the claims regarding its medicinal properties made by practitioners of traditional medicine.

The phytochemical screening of the root of Tamarindus indica (Table 1) revealed the presence of certain active constituents such as tannins, alkaloids, saponins, flavonoids, phenol and carbohydrates. Bioactive compounds such as tannins and flavonoids as found in the extract possess analgesic and anti-inflammatory activities. Flavonoids have been reported to play a role in analgesic activity primarily by targeting prostaglan- dins. ${ }^{40,41}$ These flavonoids may interact directly with the prostaglandin system and inhibit the substitute cofactor for the prostaglandin generation and also inhibit arachidonic acid lipoxygenation as well as enzymes involved with inactivation or biotransformation of prostaglandins. ${ }^{42,43}$

Tannins have astringent properties which are important in wound healing. ${ }^{44}$ There are also reports on the role of tannins in anti-nociceptive activity. ${ }^{45}$

The analgesic properties of root of Tamarindus indica were studied using two laboratory models, which allowed assessment of responses to two different types of noxious stimulus, thermal stimulus and chemicallyinduced pain stimulus. The hot-plate test is a reliable test for analgesic. Thermal stimulus-induced hyper analgesia is specific for centrally-mediated nociception while chemically induced analgesia act by causing peripherally mediated nociception. ${ }^{46}$

The analgesic activity of aqueous extract of Tamarindus indica root produced significant graded dose effects in both the models employed viz; acetic acid-induced writhing and hot plate method as compared to the ethanol extract. Writhing induced by chemical substances (e.g. acetic acid, phenyl benzoquinone) injected i.p. are due to sensitization of noci- 
ceptors by prostaglandins. ${ }^{47,48}$ and this test is useful for the evaluation of mild analgesic non-steroidal anti-inflammatory compounds. ${ }^{49,50}$

The data presented in Table 3 indicate that the plant aqueous extract showed effective analgesic activity against chemical pain induced stimulus by acetic acid in a dose-dependent manner, when compared to the standard (Aspirin) and show maximum percent inhibition than the ethanol extract.

The acetic acid induced writhing test is usually selected to study the peripheral analgesic effects of drugs and act by stimulating chemically induced pain stimulus. ${ }^{51}$ It has been suggested that intra peritoneal injection of acetic acid causes the release of endogenous mediators such as prostaglandins, especially prostaglandin E2, in peritoneal fluids. Prostaglandins activate and sensitize peripheral chemo sensitive nociceptive receptors, leading to the induction of abdominal constrictions that are accompanied by extension of the forelimbs and elongation of the body. ${ }^{52}$

The inhibition of writhing in mice by the aqueous extract suggests a peripheral mechanism of action possibly via inhibition of prostaglandins among several possibilities. Pain sensation in acetic acid-induced writhing method is elicited by triggering localized inflammatory response resulting from the release of free arachidonic acid from tissue phospholipid, ${ }^{38}$ via cyclooxygenase (COX), and prostaglandin biosynthesis in peritoneal fluids. ${ }^{53}$ The increase in prostaglandin levels within the peritoneal cavity then enhances inflammatory pain by increasing capillary permeability. ${ }^{54}$ The agent reducing the number of writhing will render analgesic effect preferably by inhibition of prostaglandin synthesis, a peripheral mechanism of pain inhibition. ${ }^{53,55}$ The significant pain reduction of the plant extract might be due to the presence of analgesic principles acting within the prostaglandin pathways. ${ }^{56}$ The effect of the extract was however; lower than that of the standard drug, Asprin and pentazocine in both the test. Peak analgesic effect was observed at a dose of $200 \mathrm{mg} / \mathrm{kg}$ in both the tests. In order to further confirm the analgesic effect of the extract, the hot plate tests were carried out. Thermal nociceptive tests are more sensitive to opioid $\mu$ receptors and non-thermal tests are to opioid $\kappa$ receptors. ${ }^{57,58}$ It measures the complex response to a non-inflammatory, acute nociceptive input and is one of the models normally used for studying central nociceptive activity. ${ }^{59}$

In the hot plate experiments, (Table 4) shows that aqueous extract of higher concentration of the Tamarindus indica had significant effect on pain latency with increased in time period when compared to the standard. While the ethanolic extract show lesser analgesic property. Since there were significant activities recorded in hot plate method the extract could be said to act both peripherally and centrally in producing analgesia. Peripherally acting analgesics such as non-steroidal anti-inflammatory drugs (NSAIDs) act by inhibiting release of prostaglandins. ${ }^{60}$ The centrally acting analgesics such as pentazocine act through their receptors in the central nervous system (CNS) by increasing the threshold response to pain stimuli. ${ }^{61}$ Opioid analgesics inhibit both peripheral and central mechanisms of pain, while NSAIDs inhibit only peripheral pain. 62, 63

Carrageenan induced hind paw oedema is the standard experimental model for acute inflammation. Carrageenan is the phlogistic agent of choice for testing anti- inflammatory drug. ${ }^{64}$ Carrageenan-induced oedema involves the synthesis or release of mediators at the injured site. These mediators include prostaglandins, especially the E series, histamine, bradykinins, leukotrienes and serotonin, all of which also cause pain and fever. ${ }^{65}$ Inhibitions of these mediators from reaching the injured site or from bringing out their pharmacological effects normally ameliorate the inflammation and other symptoms.

This study has shown (Table 5) that the aqueous extract of the root of Tamarindus indica possessed significant anti-inflammatory effect on paw oedema induced by carrageenan at certain interval and the percent inhibition is increasing with increase in time. Certain report on analgesic and anti-inflammatory activity on Tamarindus indica seed also show decrease in levels of ESR, total WBC count, lymphocytes, neutrophils and total RBC count which was estimated after giving methanol extract of Tamarindus indica and this activity may be due to presence of various active constituents in it. ${ }^{66}$

\section{CONCLUSION}

From the present study we revealed that the Tamarindus indica root extract show effective antimicrobial activity it can be a promising plant in traditional medicine for treatment of various infections. While it's aqueous extract show significant analgesic and anti - inflammatory activity providing a scientific basis for its ethnobotanical uses for alleviating pain and treating various inflammatory disorder. This investigation has opened up the possibility of the use of this plant in future for drug development and various herbal formulation having less side effects.

\section{ACKNOWLEDGEMENT}

I would like to express my thanks of gratitude to Dr Zia-Ul-Hasan, Head of Department, Botany, Safia Science College, Bhopal for his valuable support in authentification of drug. I am highly indebted to the institutional committee of Technocrates College of Pharmacy for providing laboratory and animal facility.

\section{CONFLICT OF INTEREST}

None

\section{ABBREVIATION USED}

AETIRE: Aqueous and Ethanol Tamarindus indica root extract; AAIWT : Acetic acid induced writhing test.

\section{REFERENCES}

1. Nikkon $F$, Saud ZA, Rahman $H$, Haque ME. In vitro antibacterial activity of the plant isolated from chloroform extract of Moringa oleifera. Indian J Pharma Sci 2003;22:1888-90.

2. Rahman MM, Wahed MII, Biswas MH, Sadik GM, Haque ME. In vitro antibacterial activity of the compounds of Trapa bispinosa Roxb. Med J Sci. 2000;1(4):214-6

3. Musa S Musa, Fathelrhman E Abdelrasool, Elsheikh A. Elsheikh, Lubna AMN Ahmed, Abdel Latif E Mahmoud et al. Ethnobotanical study of medicinal plants in the Blue Nile State, South-eastern Sudan. J Med Plants Res 2011;5(17):428797.

4. Lucia K keter, Patrick C Mutiso.. Ethanobotanical studies of medicinal plant used by Traditional health Practitioners in the management of Diabeties in lower eastern Provience Kenya. J Ethanopharmacol 2012;139(1):74-80. https://doi. org/10.1016/j.jep.2011.10.014; PMid:22020309.

5. El-Siddig K, Gunasena HPM, Prasa BA, Pushpakumara DKNG, Ramana KVR, Vijayanand $P$ et al. Tamarind - Tamarindus indica L. Fruits for the future. In: Williams JT, editor, Southampton Centre for Underutilized Crops, Southampton, UK; 2006.p. 31-34.

6. Doughari JH. Antimicrobial Activity of Tamarindus indica Linn. Trop J Pharm Res 2006:5(2):597-603.

7. Ramchander, Rajkumar D, Sravanprasad M, Venkateshwarlu.Goli, Dhanalakshmi CH, Arjun. Antidiabetic Activity of Aqueous Methanolic Extracts of Leaf of Tamarindus Indica L. Int J Pharmacognosy and Phytochem Res 2012;4(1):5-7.

8. Jindal V, Dingra D, Sharma S, Parel M, Harna RK . Hypolipidemic and weight reducing activity of the ethanolic extract of Tamarindus indica fruit pulp extract in cafeteria diet and sulpiride-induced obese rats. J Pharmacol \& Pharmacother 2011;2(2):80-4. https://doi.org/10.4103/0976-500X.81896 ; PMid:21772765 PMCid:PMC3127355.

9. Tayade PM, Ghaisas MM, Jagtap SA, Dongre SH. Anti-asthmatic activity of Methanolic extract of leaves of Tamarindus indica Linn. J Pharm Res 2009;2:944-7

10. Inngjerdingen K, Nergard CS, Diallo D, Mounkoro PP, Paulsen BS. An ethnopharmacological survey of plants used for wound healing in Dogonland Mali, West Africa. J Ethnopharmacol 2004;92(2):233-44. https://doi.org/10.1016/j. jep.2004.02.021; PMid:15138006.

11. Osawa T, Tsuda T, Watanabe M, Ohshima K, Yamamoto A. Antioxidative 
components isolated from the seeds of Tamarindus indica L. J Agric Food Chem.1994;42:2671-4. https://doi.org/10.1021/jf00048a004.

12. Warda S, Gadir A, Mohamed F, Bakhiet AO. Antibacterial activity of Tamarindus indica fruit and Piper nigrum. Res J Microbiol 2007;2(11):824-30. https://doi. org/10.3923/jm.2007.824.830.

13. Pimple BP, Kadam PV, Badgujar NS, Bafna AR, Patil MJ. Protective effect of Tamarindus indica Linn. against paracetamol-induced hepatotoxicity in rats. Indian J Pharm Sci 2007;69(6):827-31. https://doi.org/10.4103/0250-474X.39445.

14. Sreelekha TT, Vijayakumar T, Akanthil R. Immunomodulatory effects of a polysaccharide from Tamarindus indica. Anticancer Drugs 1993;4(2):209-12. https:// doi.org/10.1097/00001813-199304000-00013; PMid:8490201.

15. Irvine FR. London: Oxford University Press; 1961. Woody Plants of Ghana

16. Dighe NS, Pattan SR, Nirmal SA, Kalkotwar RS, Gaware VM, Hole MB. Analgesic activity of Tamarindus indica. Res J Pharmacogn Phytochem 2009;1(1):69-71.

17. Rao K, Rao M, Gobinath M, Carey MW, Kumar P, Venugopalaiah Penabaka1. Antihelmentic activity on root extract of Tamarindus indica by using different solvents . Int J Phr Res \& development 2011;2(12):56-9.

18. Ososki AL, Lohr P, Reiff M, Balick MJ, Kronenberg F et al. Ethnobotanical literature survey of medicinal plants in the Dominican Republic used for women's health conditions. J Ethnopharmacol 2002;79(3):285-98. https://doi.org/10.1016/ S0378-8741(01)00376-2.

19. Rosas R, Bustamante B, Bauer J, Fernandez I, Alban J, Lock O. Antimicrobial activity of selected puruvian medicinal plants. J Ethanopharmacol 2003;88(2):199204.

20. Colombo ML, Bassisio E. Pharmacological activities of Chelidoniummajus L (Papaveraceae). Pharmacological Res 1996;33(2):127-34. https://doi.org/10.1006/ phrs.1996.0019; PMid:8870028.

21. Watkins EA, Wollan PC, Melton LJ,Yawn BP. A population in pain- report from the Olmsted County health study. Pain Med 2000;9(2):166-174. https://doi. org/10.1111/j.1526-4637.2007.00280.x ; PMid:18298699.

22. Sosa S, Balick MJ, Arringo R, Esposito RG, Pizza C, Altinier GA. Screening of the tropical Anti - inflammatory activity of some Central American plants. J Ethanopharmacol.2002;8:211-5. https://doi.org/10.1016/S0378-8741(02)00080-6.

23. Kayaalp SO. Medicinal pharmacology in terms of rational treatment. 3rd edition, New York: Hacettepe-Tas Publication;1998.p.123

24. JB Harborne. Phytochemical methods - A guide to modern technique of plant analysis. $3^{\text {rd }}$ edition, London: Chapman and Hall Publisher;1988. p.182-190.

25. Kokate CK, Purohit AP \& Ghokhle SB. Textbook of Practical Pharmacognosy. 2nd edition. New Delhi: Vallabh prakashan; 2004.p. 21-36.

26. OECD 2002. Acute oral toxicity. Acute oral toxic class method guideline. In: Eleventh Addendum to the, OECD, guidelines for the testing of chemicals organization for economical cooperation and development, Paris, June, 2000.

27. Bauer AW, Kirby WMM, Sherris JC, Turck M. Antibiotic susceptibility testing by standardized single disc method. Am J Clin Pathol 1966;45(4):493-6. PMid:5325707.

28. Mathew AW, Donald EL, Franklin RC, Daniel JS, William AC et al. Perfor mance standards for antimicrobial Disk Suceptibility Tests, 9th ed: Approved standard;2006, p. 9-11

29. Jorgensen JH, Turnidge JD. Susceptibility test methods: Dilution and disk diffusion methods. In: Manual of Clinical Microbiology, $8^{\text {th }}$ ed:New York;ASM International; 2003.p.1108-1127.

30. Vogel GH. Drug discovery and evaluation, Pharmacological assay, $2^{\text {nd }}$ edNew York: Springer-Verlag- Berlin Heidlberg ;2002,.p. 696

31. Turner RA. Screening methods in Pharmacology, $5^{\text {th }}$ ed: New York, Acedemic press; 1965,p.100. https://doi.org/10.1016/B978-1-4832-3266-9.50012-8.

32. Ghosh MN: Fundamentals of Experimental Pharmacology, 3rd ed, Kolkata. India: Hilton and company;1984,p. 195

33. Winter CA, Risley EA, Nuss GW: Carrageenan - induced edema in hind paw of the rat as an assay for anti - inflammatory drugs. Proc Soc Exp Biol Med (NY) 1962;111:544-7. https://doi.org/10.3181/00379727-111-27849.

34. Cowan MM: Plants products antimicrobial agent. Clinical microbiology Review 1999;14:564-84.

35. Fransworth NR: Ethanopharmacology and drug discovery, Ciba foundation Symposium Wiley:Chicheter;1994,.p.42-59.

36. Lutterodt GD, Ismail A, Basheer RH, Baharudin HM. Antimicrobial effects of Psidium guajava extracts as one mechanism of its antidiarrhoeal action. Malaysian J Med Sci 1999;6(2):17-20 PMid:22589684 PMCid:PMC3329747.

37. Marjorie MC. Plant products as antimicrobial agents. Clin Microbiol Rev 1999;2(4):564-82.

38. Srinivasan D, Perumalsamy LP, Nathan S, Sures T. Antimicrobial activity of certain Indian medicinal plants used in folkloric medicine. J Ethnopharm 2001;74(3):217-2. https://doi.org/10.1016/S0378-8741(00)00345-7.

39. Alsarra Al, Ahmed OM, Alanazi KF, Alsheikh MA, Neau HS. Int J Med
Sci 2010;7:232-9. https://doi.org/10.7150/ijms.7.232 ; PMid:20617127 PMCid:PMC2899452.

40. Ahmad R, Shaari K, Lagis NH, Hamzah AS, Ismail NH, Kitayima M. Anthraquinones from Hedyotis capitellata. Phytochem. 2005;66(10):1141-7. https://doi org/10.1016/j.phytochem.2005.02.023 ; PMid:15924918.

41. Rao MR, Rao YM, Rao AV, Prabhkar MC, Rao CS, Muralidhar N. Antinociceptive and anti- inflammatory activity of a flavonoid isolated from Caralluma attenuate. J Ethnopharmacol 1998;62(1):63-6. https://doi.org/10.1016/S03788741 (98)00048-8.

42. Rajnarayan K, Reddy MS, Chaluvadi MR, Krishna. Biflavonoids classification, pharmacological, biochemical effects and therapeutic potential. Indian J Pharmacol 2001;33:2-16.

43. Recio MC, Giner RM, Manes S, Talens A, Gubells L, Gueho J. Anti-flammatory activity offlavonol glycosides from Erythrospermum monticolum depending on single or repeated local TPA administration. Planta Medica 1995;61(06):502-4. https://doi.org/10.1055/s-2006-959357; PMid:8824941.

44. Pondrimoli E, Grazi, A. A method of assaying liver hexose monophosphate oxidation. J. Comprehensive Biochem 1996;17:163-87. https://doi.org/10.1016/ B978-0-444-40695-8.50013-0.

45. Vanu MR, Palanivelu S, Panchanatham S. Immunomodulatory and anti-inflammatory effects of Semecarpus anacardium Linn. Nut milk extract in experimental inflammatory conditions. Biol. Pharmaceut. Bull 2006;29(4):693-700. https:// doi.org/10.1248/bpb.29.693.

46. Khan H, Saeed M, Gilani AU, Khan MA, Khan I, Ashraf.N Antinoci-ceptive activity of aerial parts of polygonatum verticillatum: attenuation of both peripheral and central pain mediators. Phyto Res. 2011;34:1170-3.

47. Nunez GM, Emim JA, Souccar C, Lapa AJ. Analgesic and anti-inflammatory activities of the aqueous extract of Plantago major L. Int. J. Pharmacogn 1997;35(2):99-104. https://doi.org/10.1076/phbi.35.2.99.13288.

48. Yongna Z, Wapana R, Pisit B, Zhongkun L, Rongpin Z. Analgesic and the antipyretic activities of the aqueous extract of Urtica macrorrhiza in experimental animals. Fitoterapia 2005;76(1):91-5. https://doi.org/10.1016/j.fitote.2004.10.018 ; PMid:15664468.

49. Eerkenkopf, JW, Waionmann, BM. Production of prostaglandins in mice following intraperitoneal injection of acetic acid, phenylbenzoquinone and zymosan: its role in the writhing response. Prostaglandins 1988;36(5):698-709.

50. Ferreira SH, Vane JP. New aspect on the mode of action of non-steroidal antiinflammatory drugs. Ann. Rez.Pharmacol. 1974;14(1):57-73.

51. Collier HO, Dinneen LC, Johnson, CA, Schneider C.The abdominal constriction response and its suppression by analgesic drug in the mouse. British Journal of Pharmacology and Chemotherapy 1968;32(2):295-310. https://doi. org/10.1111/j.1476-5381.1968.tb00973.x ; PMid:4230818 PMCid:PMC1570212.

52. Derardt R, Jongney S, Delvalcee F, Falhout M. Release of prostaglandins $E$ and $F$ in an algogenic reaction and its inhibition. Eur J Pharmacol 1980;61(1):17-24. https://doi.org/10.1016/0014-2999(80)90377-5.

53. Duarte IDG, Nakamura M, Ferreira SH. Participation of the sympathetic system in acetic acid-induced writhing in mice. Braz J Med Biol Res 1988;21(2):341-3. PMid:3203167.

54. Zakaria ZA, Abdul-Ghani ZDF, Raden M, Nor RNS, Gopalan HK, Sulaiman MR et al. Antinociceptive, anti-inflammatory, and antipyretic properties of an aqueous extract of Dicranopteris linearis leaves in experimental animal models. J. Nat. Med 2008;62:179-87. https://doi.org/10.1007/s11418-007-0224-x ; PMid:18404320.

55. Ferdous M, Rouf R, Shilpi JA, Uddin SJ. Antinociceptive activity of the ethanolic extract of Ficus racemosa Linn. (Moraceae). Orient. Pharm. Exp. Med .2008;8(1):93-6. https://doi.org/10.3742/OPEM.2008.8.1.093.

56. Ukwuani NA, Hassan FF. Analgesic properties of Tamarindus indica L. stem bark fractions in albino rats. Sky J. Biochem. Res 2014;3(2):24-7

57. Abbott F, Young SN. Effect of 5-hydroxy tryptanin precursors on morphine analgesia psychotria colorata (Wild ex R and S).muell arg. Alkaloids. J. Ethnopharmacol 1995;48(2):77-83. https://doi.org/10.1016/0378-8741(95)01287-N.

58. Pal S, Sen T, \& Chaudhuri AK. Neuropsychopharmacological profile of the methanolic fraction of Bryophyllum pinnatum leaf extract. J. Pharm. Pharmacol 1999:51(3):313-8. https://doi.org/10.1211/0022357991772312 ; PMid:10344633.

59. Chakraborty A, Devi RK, Rita S, Sharatchandra K, Singh TI. Preliminary studies on antiinflammatory and analgesic activities of Spilanthes acmella in experimental animal models. Indian J. Pharmacol 2006;36(3):148-50.

60. Asongalem, EA, Foyet HS, Ekoo S, Dimo T, Kamtchouing P. Anti-inflammatory, lack of central analgesia and antipyretic properties of Acanthus montanus (Ness). J Ethnopharmacol 2004;95(1):63-8. https://doi.org/10.1016/j. jep.2004.06.014; PMid:15374608

61. Anupama A Suralkar, Kishor N Rodge, Rahul D Kamble, Kanchan S Maske. Evaluation of Anti-inflammatory and Analgesic Activities of Tamarindus indica Seeds. Int J Pharma Sci Drug Res 2012;4(3):213-7. 


\section{SUMMARY}

- The Phytochemical and Pharmacological research conducted on the root of Tamarindus indica shows presence of certain chemical constituents such as tannins, flavonoids and alkaloids \& pharmacologically it shows antibacterial property on certain microorganism and analgesic (Hot plate \& AAWT ) and antiinflammatory (Carrageenan induced paw oedema) activity in rats. The Ethanol extract act as a potent antimicrobial agent while aqueous extract is effective as analgesic and anti-inflammatory agent.

\section{ABOUT AUTHORS}

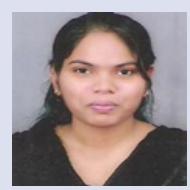

Sangeeta Gupta: Currently working as an Assistant Professor in Moradabad group of Institution, Faculty of Pharmacy in Pharmacognosy Department, Moradabad. Pursued B. pharm and M. pharm from reputed Institute with Honours. Has 4 years of teaching experience and 1 year Industrial experience. Had worked as a trainee in National Dope Testing Laboratory, New Delhi and guided various undergraduate students in their projects. She had published various articles in National and International journals and attended various seminars and Conferences.

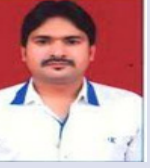

Amit Singh: Presently working as an Assistant Professor in Shri Gopichand College of Pharmacy, Pharmacology Department, Baghpat (UP). Pursued B.pharm and M.pharm from a reputed Institution with honours degree in Post-graduation. Has more than 5 years of teaching experience in various colleges. Published various articles in National and International journals and attended various seminars and Conferences.

Cite this Article: Gupta S, Singh A. Antimicrobial, Analgesic and Anti - Inflammatory Activity Reported on Tamarindus indica Linn Root Extract. Pharmacogn J. 2017;9(3):410-6 